\title{
Випадок рідкісного ускладнення гнійного інфі.льтративного ларингіту
}

\author{
H. K. BARTOSH, T. V. MURAVYOV, V. V. ARTIUKH
}

Zhytomyr Region Clinical Hospital by O. F. Herbachevskyi

\section{A CASE OF RARE COMPLICATION OF PURULENT INFILTRATIVE LARINGITIS}

Гострий медіастиніт - гостре гнійне запалення клітковини межистіння, що виникає в результаті ускладнення різноманітних захворювань. Гнійне запалення, запалення клітковини межистіння, перебігає, як правило, у вигляді флегмони. Цьому сприяють анатомічні та фізіологічні особливості межистіння (рихла жирова клітковина, відсутність фасціальних бар’єрів, постійні дихальні рухи, пульсація серця та центральних судин). Висока всмоктувальна здатність приводить до швидкої вираженої інтоксикації та летального виходу протягом 1-5 діб від початку захворювання. Летальність при гострому медіастиніті, за даними різних авторів, сягає від 7,2 до $70 \%$.

За 10 років у відділенні ЖОКЛ лікували 73 хворих на гострий медіастиніт. 3 них чоловіків було 39 (52 \%), жінок - 34 (48 \%). Віком 18-40 років - 26 (35,6 \%), 41-60 років - 30 (41,6 \%), 61 та старші $17(23,3 \%)$.

Із 73 пацієнтів у 38 (52,3 \%) хворих мала місце гнійна патологія щелепно-лицевої зони, у 18(24,9\%) хворих - патологія ЛОР-органів, у 7 (10,2 \%), хворих - перфорація стравоходу, інфільтративнофлегмонозний ларингіт - у 2 (2,7 \%) пацієнтів.

Хвору В. віком 57 років госпіталізовано в реанімаційне відділення Житомирської обласної клінічної лікарні 07.05.13 р. о 17:15 у тяжкому стані переводом з реанімаційного відділення ЦМЛ № 2 м. Житомира зі скаргами на біль у лівій половині шиї, що посилюється при ковтанні, задишку, сухість у роті, виражену загальну слабість, підвищення температури тіла до $38^{\circ} \mathrm{C}$. Вважає себе хворою з 30.04.13 р., коли з'явився біль у горлі при ковтанні, підвищилась температура тіла до 38 C. Лікувалася самостійно (полоскання горла “Хлорофіліптом”, компреси з 30 \% димексидом на ділянку шиї). У зв’язку з погіршенням стану 02.05.13 р. госпіталізована в ЛОР-відділення ЦМЛ № 2 м. Житомира з діагнозом інфільтративного ларингіту, термічного опіка I ступеня передньої поверхні шиї. Призначено ан- тибактеріальну терапію (цефтріаксон). Стан хворої не поліпшувався. 05.05.13 р. проведено рентгенографію ОГП, при якій виявлено лівобічний гідроторакс. Оглянута хірургом, проведено пункцію лівої плевральної порожнини, отримано гній, після чого виконано дренування плевральної порожнини за Бюлау: виділилося 1,5 л гною і хвору переведено в хірургічне відділення. 06.05.13 р. оглянута консиліумом лікарів у складі начмеда, завідувачів хірургічного та реанімаційного відділень, оториноларинголога. Встановлено діагноз: емпієма плеври зліва; гострий інфільтративний ларингіт; цукровий діабет, тип 2, вперше виявлений. Хвору переведено в реанімаційне відділення, де проведено додаткове дренування лівої плевральної порожнини. 07.05.13 р. виконано КТ ОГП з внутрішньовенним підсиленням. При цьому встановлено: інфільтративний процес переднього середостіння і передніх просторів шиї - некротизуючий медіастиніт, емпієма плеври зліва з множинними осумкуваннями. Викликаний на консультацію торакальний хірург встановив діагноз інфільтративного ларингіту у фазі абсцедування, медіастиніту, лівобічного піопневмотораксу з множинними осумкуваннями і доставив хвору реанімобілем в обласну лікарню 07.05.13 р. о 17:15. Після короткочасної передопераційної підготовки 07.05.13 р. о 19:15 проведено операцію - розкриття i дренування флегмони дна порожнини рота, глибокої міжфасціальної флегмони шиї зліва, розкриття і дренування заднього середостіння, розкриття абсцесів гортаноглотки. Під час операції в превертебральній фасції виявлено гній, при ревізії знайдено гнійну порожнину, яка поширюється від навкологлоткового простору до лівого крилощелепного простору і за ходом стравоходу глибоко в заднє середостіння. Виділилося до 200 мл гною. Ходу в переднє середостіння не виявлено. У післяопераційному періоді призначено антибактеріальну терапію (меропенем - 1,0 3 рази на день внутрішньовенно), дезінтоксикаційну терапію, постійний лаваж дре- 
нажів антисептиками (декасан, гіпохлорид натрію, октанісепт), корекцію глікемії. 12.05 .13 р. дренаж лівої плевральної порожнини перестав функціонувати. Виконано редренування плевральної порожнини. На 6-ту добу після операції стан хворої без помітного поліпшення, по дренажу з середостіння виділилося за добу 200 мл серозно-гнійного вмісту. 3 лівої плевральної порожнини - 350 мл гнійного вмісту. Проведено контрольне КТ ОГП, при якому встановлено картину медіастиніту з локалізацією патологічних змін переважно у верхньому і середньому поверхах середостіння, більше зліва з ознаками поширення на ліву плевральну порожнину парамедіастинально і паракостально допереду на рівні верхньої частки лівої легені на фоні дренування заднього середостіння. Двосторонній гідроторакс, з ознаками емпієми плеври зліва з вираженим осумкованням на фоні дренування лівої плевральної порожнини. Враховуючи від'ємну динаміку, за даними КТ ОГП, 13.05.13 р. проведено операцію - ревізію і дорозкриття гнійних затікань шиї з обох сторін, тотальне дренування переднього середостіння, бокову торакотомію зліва, тотальне дренування заднього середостіння і редренування лівої плевральної порожнини. Під час операції при ревізії виялено додаткові затікання в претрахеальний і ретротрахеальний простори, правий крилопідщелепний простір і переднє середостіння. При ревізії переднього і заднього середостіння дно порожнини не досяжне. Вирішено виконати тотальне дренування переднього середостіння і дренування заднього середостіння через лівобічну торакотомію. Виконано розріз завдовжки до 5 см по середній лінії живота від мечоподібного відростка і нижче. Екстраперитонеально відшаровано діафрагму. Розкрито переднє середостіння отримано гній. Дренування гнійних затікань шиї і середостіння 8-ма ПХВ дренажами. При торакотомії зліва в плевральній порожнині до 500 мг гнійного геморагічного вмісту. Плевра потовщена, покрита фібрином, в задньому середостінні - секвестри і гній. Заднє середостіння розкрито до дуги аорти, плевральну порожнину дреновано двома дренажами. Після операції проводили інтенсивну й антибактеріальну терапіюю 04.06.13 р. при рентгенографії стравоходу на рівні груднино-ключичного з'єднання відзначається затікання контрасту вліво, допереду за межі стравоходу. При ЕФГДС на відстані 27 см від різців виявлено дефект стінки стравоходу розміром $1 \times 0,5$ см. Хворій налагоджено ентеральне харчування через зонд, який видалено через три тижні. 06.06.13 р. хвору переведено в торакальне відділення. Поступово видалено дренажі з середостіння і плевральної порожнини. 29.06.13 р. хвору виписано додому в задовільному стані. Оглянуто через три тижні і через два місяці: стан задовільний, ковтання вільне.

У Житомирській області лікування хворих на флегмону шиї та медіастиніт затверджено наказом УОЗ ЖОДА № 294 від 06.03.15 р. Згідно з наказом до лікування залучаються спеціалісти: щелепнолицевий хірург, оториноларинголог, загальний хірург, ендоскопіст, лікар інтенсивної терапії.

Перевага віддається активній хірургічній тактиці. Проводиться інтенсивна дезінтоксикаційна, інфузійна та антибактеріальна терапія. Операційне лікування здійснюється протягом 2-х год від моменту госпіталізації. При флегмоні шиї віддається перевага інтубації трахеї по бронхоскопу. Проводяться постійні санації трахеобронхіального дерева з регулярними санаційними фібробронхоскопіями.

Завдяки активній хірургічній тактиці та адекватній інтесивній терапії нам вдалося зменшити летальність до 12,5 \%. 